\title{
Blood vessels of the ciliary ganglion in man
}

\author{
M. ELIŠKOVÁ \\ Institute of Anatomy, Faculty of Medicine, Charles University, Prague, Czechoslovakia
}

Many authors, including Egorov (I 886), Beauvieux and Dupas (I926), Winckler (I 93 I), Christensen (1936), Kurus (1956), and Grimes and von Sallmann (1960), have made.anatomical and histological studies of the ciliary ganglion in man and various animals. $\vec{\circ}$ They have given detailed descriptions of its macroscopical, topographical, and cytologicalö properties, but without mentioning the blood supply. Only Kuznetsova (1963) haso studied the vascular system of the ciliary ganglion in human foetuses and neonates. The present communication treats this subject in more detail, with special reference to anO earlier study of the vascularization of the ciliary ganglion in the rhesus monkey (Elišková, 0 I969).

\section{Material and methods}

Eighteen human orbits, four of them foetal, were studied. After the introduction of a cannula info@ the internal carotid artery, the arterial network was injected, first with a mixture of Indian ink and o per cent. gelatin and then, after the dye had appeared in the conjunctival vessels, with anothero mixture consisting of barium and minium suspended in 7 per cent. gelatin. This was followed by an injection of io per cent. formalin into the retrobulbar space. After the substance injected into $\overrightarrow{\vec{O}}$ the arteries had solidified, the orbit was exenterated and its contents fixed in ro per cent. formalin. 3 The vessels were traced under the binocular dissecting microscope, special attention being paid to the blood supply to and drainage from the ciliary ganglion. Four specimens of orbital contents: were prepared for histological examination by serial sections in the sagittal and frontal planes and응. staining with Masson's trichome.

\section{Observations}

The ciliary ganglion is a flat or lenticular organ with a medial and lateral surface, orientated? in a sagittal plane, in close proximity to the ophthalmic artery (Fig. I) and lying justo below its lower circumference and lateral to the optic nerve. Anteriorly, it may extend as far as the site where the artery bends to run across the nerve. Only in one case, in which ${ }^{\circ}$ the ophthalmic artery crossed the lower surface of the optic nerve, did the ganglion reach $\tilde{O}^{0}$ this angle. (However, this may be regarded as a variation in the course of the artery rather than as a variation in the position of the ganglion.) In six cases, the medial surface of the ganglion touched the posterior branches of the opthalmic artery, the central arterye of the retina, and the posterior lateral ciliary artery.

The ciliary ganglion is supplied with blood by one to four branches of neighbouring arteries. This was the posterior lateral ciliary artery (in eleven cases), the trunk of the 


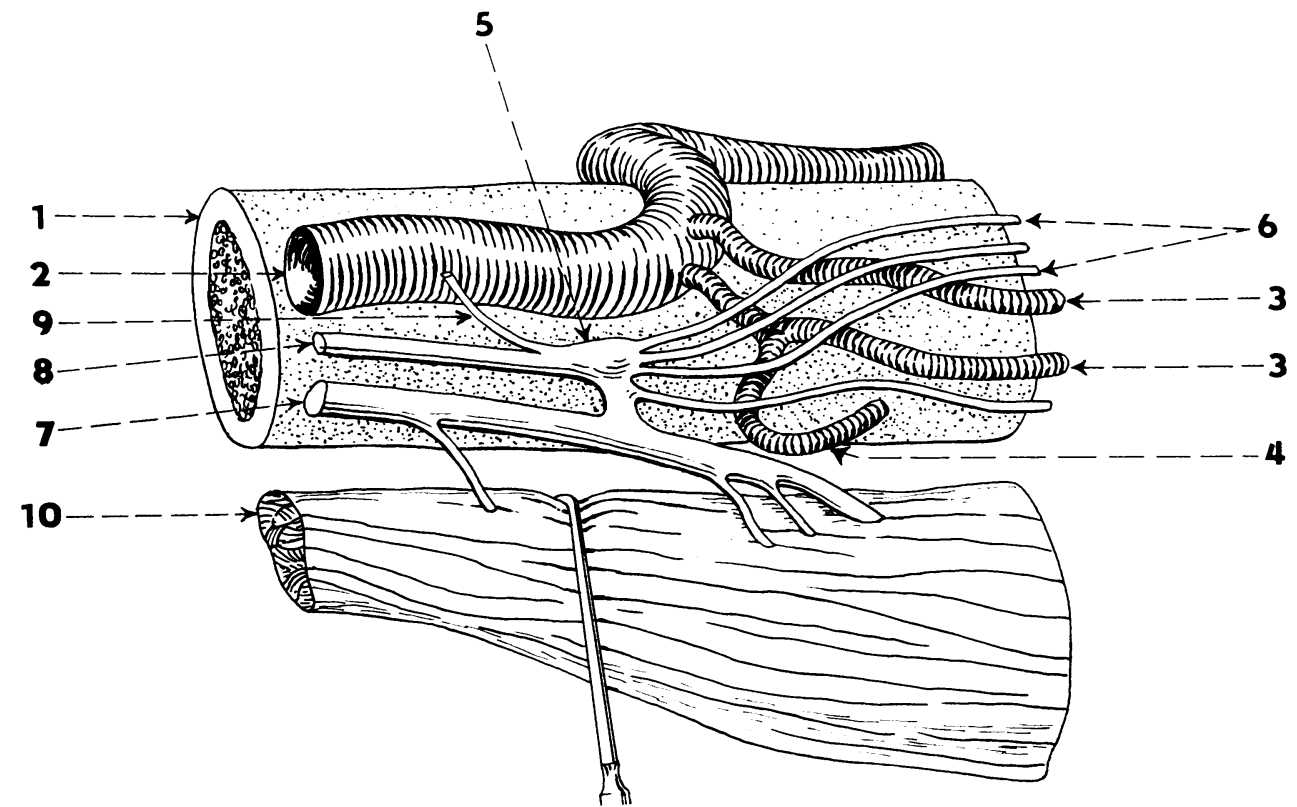

FIG. I Ciliary ganglion and its relationship to arteries, viewed from external side of orbit.

I-optic nerve

2-ophthalmic artery

3 - posterior lateral ciliary artery I, 2

4 - central artery of the retina

5-ciliary ganglion
6 -short ciliary nerves

7 -ramus inferior of the oculomotor nerve

8 -ramus communications cum nasociliari

9-radix sympathica

Io-lateral rectus muscle

lateral muscular artery, its small branches supplying the rectus lateralis and inferior (in eleven cases) (Fig. 2), and special branches of the ophthalmic artery, which supply blood to the retrobulbar space (in seven cases). In three cases these branches came from the central artery of the retina and in two firm cases the vascular network of the optic nerve. The arteries of the ciliary ganglion were also frequently found to supply blood to the short ciliary nerves and the ramus inferior of the oculomotor nerve. One ganglion

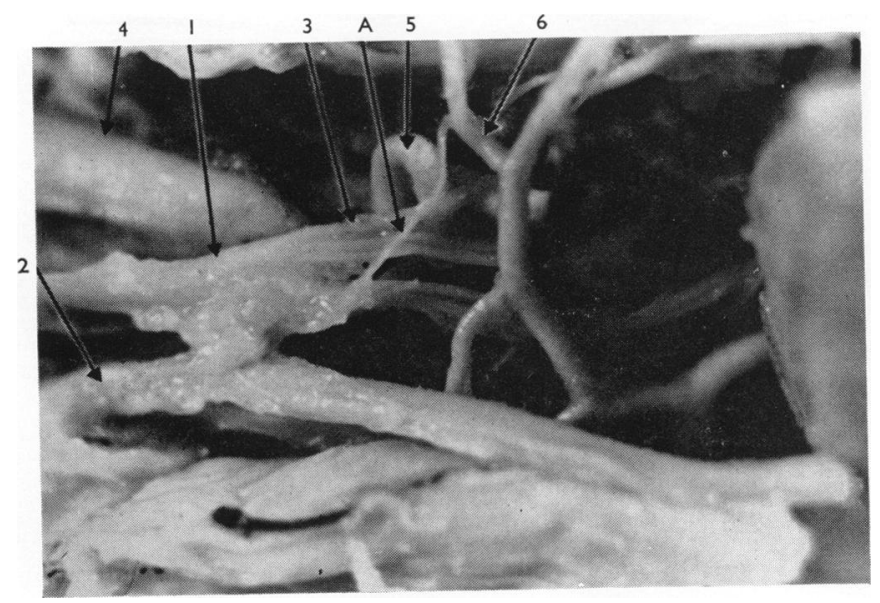

FIG. 2 Artery $(A)$ from lateral muscular arterial trunk entering ganglion, viewed from external side of orbit

I-ciliary ganglion 2-oculomotor nerve 3-short ciliary nerves

4-ophthalmic artery

5- posterior lateral ciliary artery 6-trunk of muscular artery A-branch to ganglion 
Table Origin of arterial branches supplying ciliary ganglion

\begin{tabular}{|c|c|c|c|c|}
\hline Origin & & \multicolumn{3}{|c|}{ No. of branches } \\
\hline Lateral posterior ciliary artery & & I I & & \\
\hline Trunk of lateral muscular artery & & I I & & \\
\hline Ophthalmic artery & & 7 & & \\
\hline Central retinal artery & & 3 & & \\
\hline Vascular network of optic nerve & & 2 & & \\
\hline No. of branches for one ganglion & I & 2 & 3 & 4 \\
\hline No. of cases & 5 & Io & 2 & I \\
\hline
\end{tabular}

may have up to three arterial sources (see Table). The branches originating from the of posterior lateral ciliary artery supply blood to the anterior half of the ganglion, running $\vec{\circ}$ backwards and frequently bifurcating into two branches, one each for its medial and lateral surface. The branches originating from the muscular trunk most frequently enter the ganglion on its lateral aspect, while those of the central artery of the retina enter more often on its medial aspect (Fig. 3). The course of all the other arteries is variable, depending on their site of origin. Unlike the veins, the arteries do not branch before entering the ganglion, but simply plunge into the tissue. The calibre of the arteries supplying blood to the ganglion is very small, between 40 and $60 \mu$.

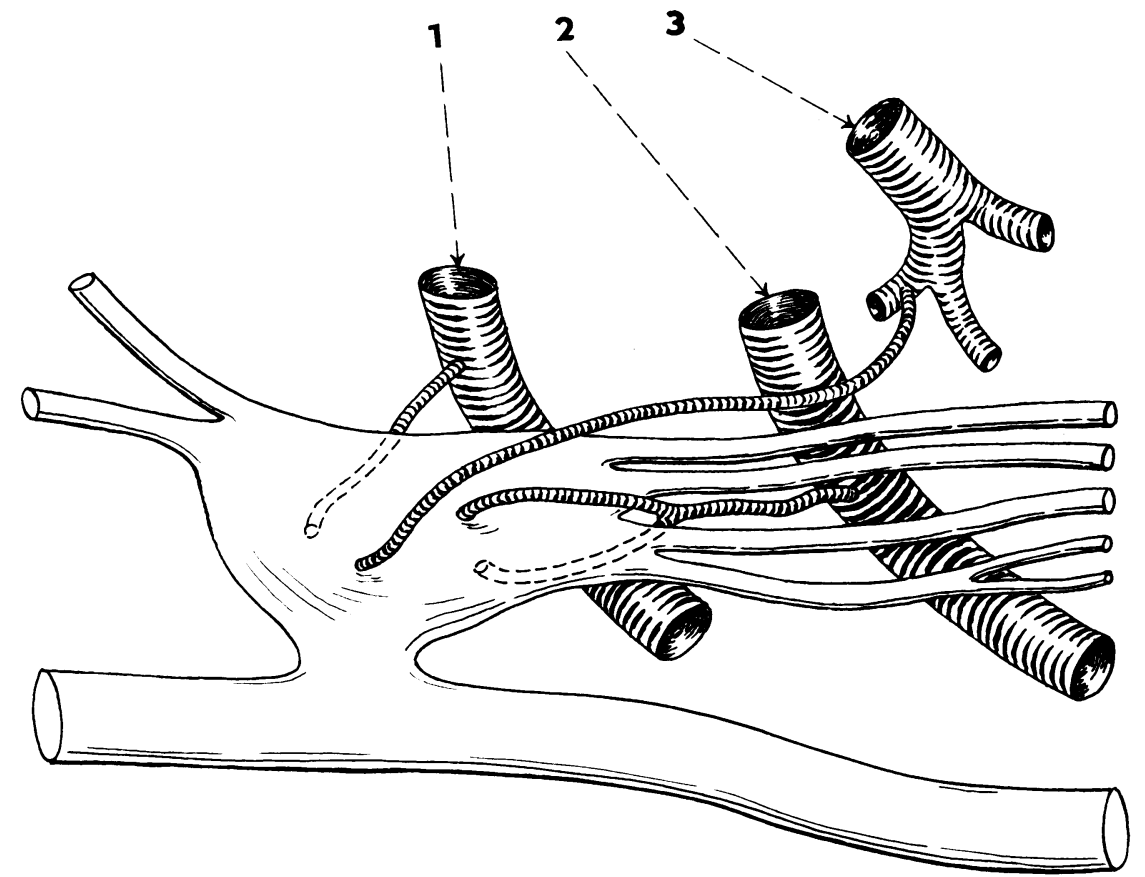

FIG. 3 Typical localization of arteries entering ganglion, viewed from external side of orbit 
The veins form networks on the medial and lateral aspects of the ganglion, which reach up to the edges of the organ, and veins proceed thence without regular arrangement (Fig. 4). Like the arteries, the veins of the ganglion link up with those draining blood from the short ciliary nerves and the adjacent part of the oculomotor nerve. Two to four veins leave the ciliary ganglion, and after an intraorbital course of various lengths, empty themselves into several vessels-the muscular branches of the rectus lateralis and inferior, and the vein running in the retrobulbar connective tissue. Only in six cases was one of the ganglion veins found to be linked up with the venous network in the coats of the optic nerve, and in two cases with the central vein of the retina. The terminal vein draining blood from the ganglion was the inferior ophthalmic vein in most cases.

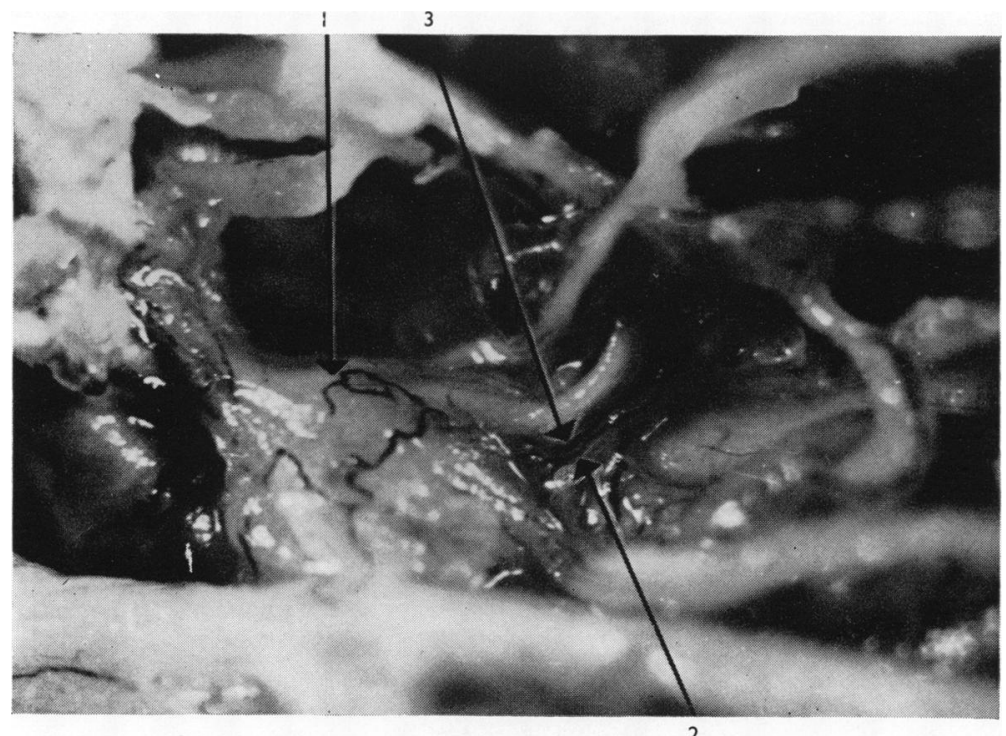

FIG. 4 Ciliary ganglion with superficial venous network. The artery and vein run together to the anterior part of the ganglion. Viewed from lateral side

I-ciliary ganglion 2-artery (thin), branch of the posterior ciliary artery

3 -one of draining veins (thick)

The vascular bed proper of the ciliary ganglion is formed by a network of large, irregular, not very dense capillary meshes of various calibres. The orientation in space of this network can be seen from the histological slides. In the frontal sections, the vessels are cut across (Fig. 5), while in the sagittal sections (parallel to the ganglion surface) the

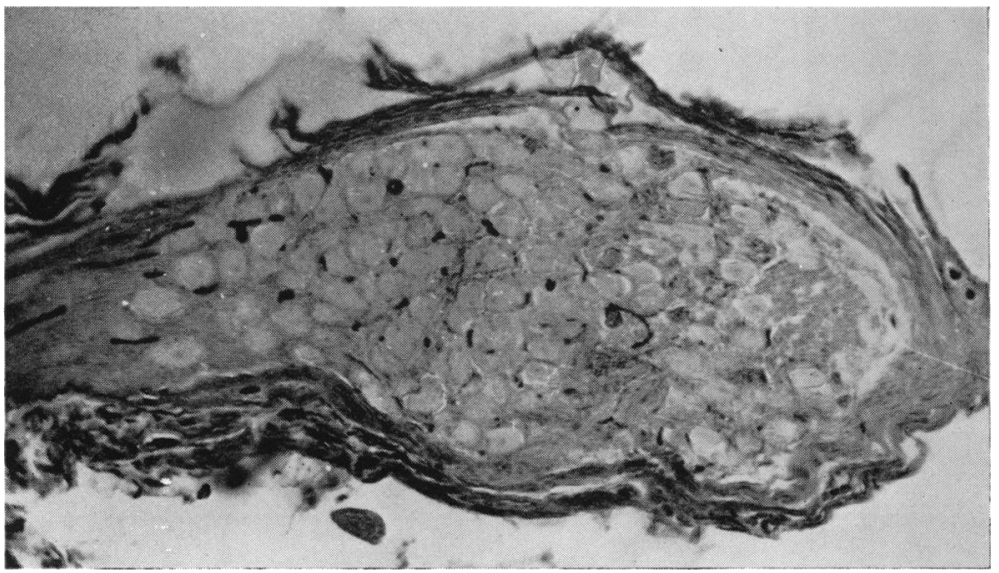

FIG. 5 Section of ciliary ganglion cut in frontal plane, showing capillaries mostly cut across. $\times 3^{2}$ 
vessels are cut longitudinally as well as transversely (Fig. 6). This permits the conclusion that the capillary network is chiefly orientated sagittally.

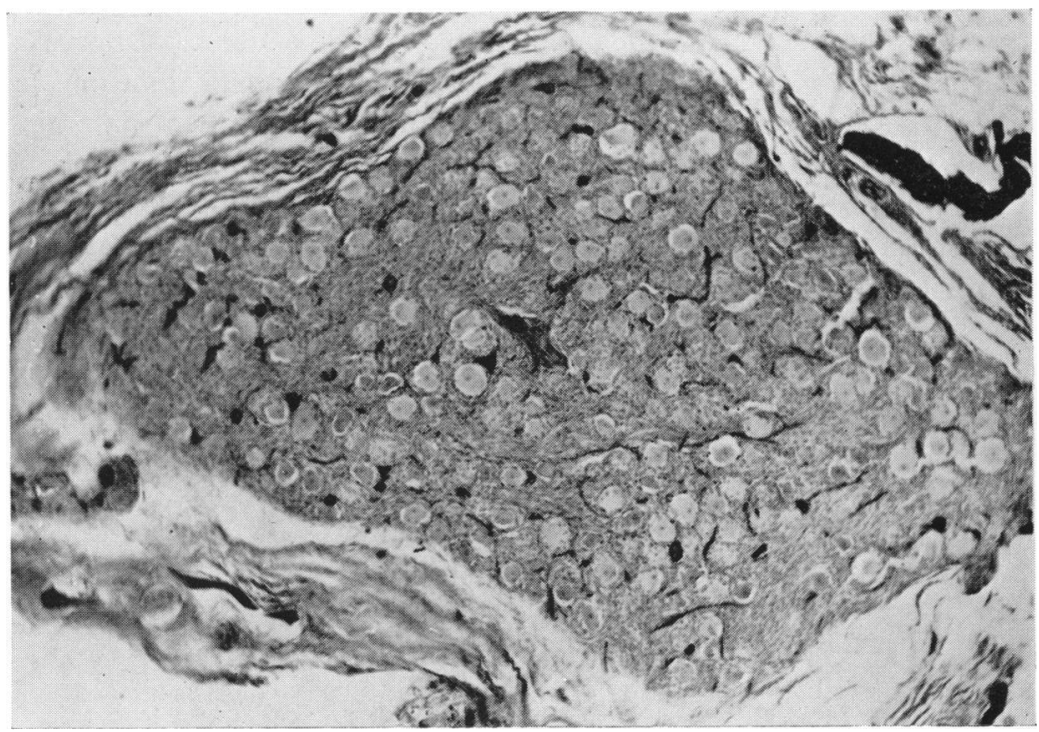

FIG. 6 Section of ciliary ganglion cut in sagittal plane. Vessels are cut longitudinally as well as transversely. $\times 32$

The polygons formed by the capillary meshes of the ganglion are very irregular and show a close relationship to the ganglion cells. This becomes most conspicuous at the site where a nerve leaves the ganglion, and scattered ganglion cells, together with their capillar meshes, follow the origin of this nerve (Fig. 7). The vessels of the nerve itself are fevo. in number and run longitudinally.

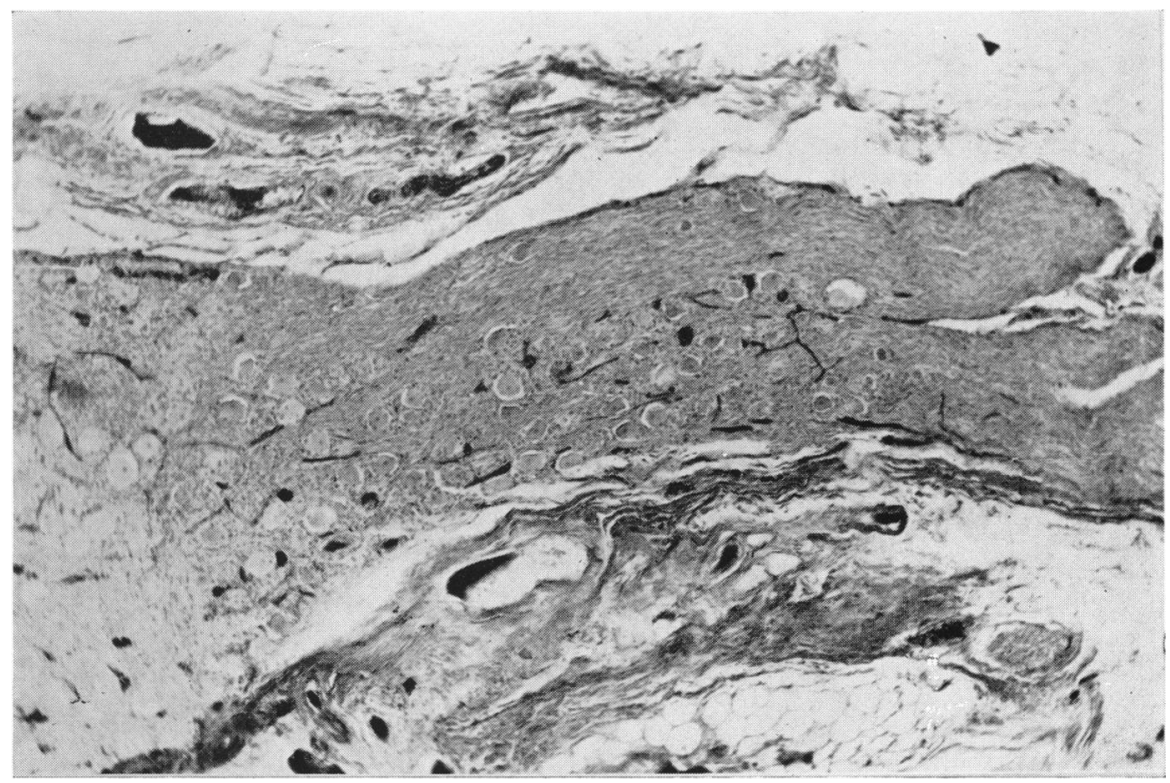

FIG. 7 Nerve leaving ciliary ganglion. Capillaries form irregular meshes around scattered ganglion cells. $\times 30$ 


\section{Discussion and conclusions}

As has been shown by anatomical studies in man, the ciliary ganglion is an organ of most variable size and shape (Beauvieux and Dupas, I926; Winckler, I93 I ;Wolff, I 948; Kurus, I 956; Grimes and Sallmann, I96o). This has been confirmed by the present investigation; in some of the cases examined, there was no macroscopic ganglion structure at all. In the rhesus monkey (Elišková, I969), unlike in man, the ciliary ganglion represents a compact and well defined lenticular structure which is about the same size in every subject. The ganglia of the rhesus monkey and human foetus are similar in appearance. The relationship of the ciliary ganglion to the vascular trunks in the orbit was described by Beauvieux and Dupas (1926). The ganglion actually touched the ophthalmic artery in 38 per cent. of their series of eighty cases. However, these authors do not analyse the course of the artery in more detail. In the present investigation, the medial surface of the ganglion was found in immediate relation to the ophthalmic artery in the only case in which this artery crossed beneath the optic nerve. Contrary to the findings of the authors referred to above, no arteries were found to pierce the ganglion, and only the posterior lateral ciliary artery lay in close relation to the short ciliary nerves. In one case, the ciliary ganglion lay with its medial surface on separated fibre bundles of the rectus inferior. These bundles joined the muscle on its medial aspect just before its entry into the sclera, and thus separated the ganglion from the optic nerve.

In her description of arteries, the author has used the classification referred to by Hayreh (1962).

Kuznetsova ( 1963 ), who studied the blood supply to the ciliary ganglion in human foetuses and neonates, described two to three arteries which reach the ganglion from the short posterior ciliary arteries supplying the anterior pole, and from the ophthalmic artery supplying the posterior pole. She did not mention the muscular branches which were frequently found in the present study.

In comparing the blood vessels of the ciliary ganglion in man with those in the rhesus monkey, the muscular branches are seen to be more frequent in the former, while small branches of the ophthalmic artery, originating even from its intracanalicular part, usually occur in the latter, frequently with small branches of the central artery of the retina.

The vascular network of the ciliary ganglion is not as dense in man as in the rhesus monkey. The meshes are larger and of unequal size, and the vessels have different calibres, forming irregular polygons; moreover, the network itself occupies more space. In the rhesus monkey, on the other hand, the network is rather flat and is orientated in a sagittal plane, and the capillaries are of the same calibre, forming polygons around the ganglion cells. There are more ganglion cells in the rhesus monkey than in man and this may account for the differences in the density of the capillary blood supply.

\section{Summary}

After injecting the vascular bed of the orbit in eighteen specimens, the vascular system of the ciliary ganglion was investigated. The ganglion is in close proximity to the ophthalmic artery, and, in one-third of the cases lay with its medial surface on the arterial branches of the central artery of the retina and the posterior lateral ciliary artery.

The arterial branches supplying blood to the ganglion most frequently originate from the posterior lateral ciliary artery (supplying the anterior half of the ganglion) and from the lateral muscular arterial trunk (entering the ganglion from its lateral side).

Blood is drained from the ganglion by two to four veins (which form anastomoses on the 
surfaces of the organ) into the veins of the retrobulbar space and muscular branches, and through them usually into the inferior ophthalmic vein.

The vascular bed of the ganglion is formed by an irregular network of moderate density in close relationship to the ganglion cells, which they accompany to the roots of the ganglion nerves. This network is orientated more or less parallel to the surfaces of the ganglion. In comparison with the vascular system of the ciliary ganglion in the rhesus monkey, branches of muscular arteries are found more frequently in man, while those of the ophthalmic artery and the central artery of the retina are found more often in the rhesus monkey. In man, the capillary meshwork does not form typical polygons, and the ganglion cells appear to be less numerous than in the rhesus monkey.

\section{References}

Beauvieux and Dupas, J. (1926) Arch. Ophtal., 43, 64I

Ghristensen, к. (1936) J. Anat. (Lond.), 70, 225

Egorov, J. (1886) Arch. slav. Biol. (Paris), 2, 376

ELIŠKovÁ, м. (I969) Brit. J. Ophthal., 53, 753

Grimes, P., and Sallmann, L. von (1960) Arch. Ophthal. (Chicago), 64, 8I

HAYREH, s. s. (1962) Brit. F. Ophthal., 46, 212

kURus E. (1956) Klin. Mbl. Augenheilk., 129, 183

KUZNETSOVA, L. v. (I963) "Trudy šestoj naučnoj konferencii po vozrastnoj morfologii, fysiologii i

biochimii, Moskva", p. 106

Winckler, G. (193 I) Arch. Anat. Histol. Embryol., 14, 303

WolfF, E. (1948) "The Anatomy of the Eye and Orbit", 3rd ed. Lewis, London 